\title{
Results on bioenergetic potential of some sweet sorghum hybrids cultivated under psamosols conditions in Southern Oltenia
}

\author{
Iulian Draghici ${ }^{*}$, Reta Draghici $^{1}$, Aurelia Diaconu ${ }^{1}$, Mihaela Croitoru ${ }^{1}$, \\ Alina Nicoleta Paraschiv ${ }^{1}$, Milica Dima ${ }^{1}$,Elena Ciuciuc ${ }^{1}$ and Daniel Ciuciuc ${ }^{1}$ \\ ${ }^{1}$ Research Development Station for Plant Culture on Sands Dabuleni, 207170, Călărași, Dolj, \\ Romania
}

\begin{abstract}
Sorghum bicolor L. Moench is a herbaceous annual C4-type plant, with a high ecological plasticity because it can be grown in tropical, subtropical, temperate and semi-arid regions, harnessing soils with reduced natural fertility, from the category of sandy soils. Studies on 5 sweet sorghum hybrids studied under psamosols in southern Oltenia highlight a bioenergy potential in the milk-wax phase of the grain, ranging from 60847.4-89338.65 Mcal / ha, with a maximum in the hybrid Shaşm 2, which achieved a distinctly significant difference in production, compared to the average production of hybrids. The results recorded in sugar sorghum production were positively correlated, significantly distinct with leaf index determined during the flowering of the plants $\left(\mathrm{r}=0.9854^{* *}\right)$.
\end{abstract}

\section{Introduction}

Sorghum (Sorghum bicolor L. Moench) is an annual herbaceous C4 plant with a high ecological plasticity, as it can be cultivated in tropical, subtropical, temperate and semi-arid regions, harnessing the soils with low natural fertility, from the category of sandy soils. Due to the high content of sweet juice in the stems and the high proportion of starch from the grains, sweet sorghum (Sorghum bicolor var. saccharatum or simplified Sorghum saccharatum) is one of the most important agricultural sources used for production of biomass that can be processed and converted relatively easy into a type of fuel (bioethanol, synthesis gas), vegetable proteins, food for animals or green manure $[1,3,5]$. Renewable energy is a critical source of energy that contributes to energy security, reducing dependence on fossil fuels and greenhouse gas emissions. Studies in India show a need of more than 6.3 billion litres of ethanol to achieve its target of replacing $20 \%$ of oil fuel with biofuel consumption (bioethanol and biodiesel) by 2017, according to Ethanol Blending Program (EBP) [10]. It shows the importance of the sweet sorghum for renewable energy in India, stating that the plant is a promising biological raw material for dry areas, which is addressing favourably the problem of supplying with superior fuels. The widespread cultivation of sweet sorghum is achievable if cultivation with increased yield of sugar with multiple tolerance to biotic and abiotic stress are available. Sweet sorghum is widely

\footnotetext{
*Corresponding author: iuliandraghici54@yahoo.com
} 
acknowledged as a highly promising energy culture for biomass with special potential to complement the production of sugar cane in diversified culture systems [6]. The Research carried out at the Agricultural Centre of the Louisiana State University, shows that the percentage of sugar in the strains was different depending on the hybrid taken in the study, and varied in the range $12.7 \%-15.1 \%$. The results obtained in a study at Giza Agricultural Research Station, Giza Governorate, Egypt, highlighted the use of various forms of sweet sorghum syrup for the manufacture of cakes [13]. The chemical properties indicated that the syrup and the lyophilised juice from the sweet sorghum were rich sources in both sugars and minerals ( $\mathrm{K}, \mathrm{Ca}$ and $\mathrm{Fe}$ ). Due to its genetic variability, with regard to the sugar content of the stem, such as total soluble sugars, the yield of green stem, the quantity of juice and the yield of grains, various research institutes in the country and abroad have developed varieties and hybrids of the culture of sweet sorghum. In our country, the research undertaken by I. Antohe, [8], on the chernoziom of Fundulea, highlighted that the average sugar productions in the strains were between 4.6-6.3 t/ha in the Carmen variety and 6.88.5 to the simple hybrid Doina.

Under the current conditions of aridization of the climate, the identification of agricultural practices with the potential to mitigate the impact of climate change on the security of agricultural production is increasingly more interesting. In this context, the orientation towards drought-resistant crops is shaped as an alternative solution. Sweet sorghum is one of the cultures with high adaptability to slightly favourable ecological conditions (poor soils, arid climate), due to the high capacity to efficiently exploit natural resources and it's increased tolerance to drought.

\section{Methodology}

The research carried out at Research Development Station for Plant Culture on Sands Dăbuleni (RDSPCS Dabuleni), aimed at the conduct of 5 sweet sorghum hybrids in the conditions of the sandy soils of southern Oltenia. The sowing was made in the first decade of May, at $70 \mathrm{~cm}$ between the rows, ensuring a density of 15-20 germinable grains $/ \mathrm{m}^{2}$. The experience was placed after the method of randomized blocks, in three repetitions, on a sandy soil with a accentuated non-uniformity from a chemical point of view. The soil quality analyses where the experience was located highlighted a nitrogen content of between $0.035 \%$ and $0.13 \%$, values indicating a low soil supply state, an extractable phosphorus content between $59 \mathrm{ppm}$ and $115 \mathrm{ppm}$, values, that characterizes the soil as well stocked in phosphorus, and a percentage of $24 \mathrm{ppm}$ to $62 \mathrm{ppm}$ in replaceable potassium, which shows a low-medium supply state. Organic Carbon presented values in the range $0.19 \%-0.65 \%$, indicating a state of supply of soil in low organic matter, with portions to the middle, and the soil $\mathrm{pH}$ oscillated between 4.83 and 6.13 , values showing a moderately strong acid reaction to poorly acidic.

Morphological, biometric, physiological and quality measurements of the biomass obtained have been carried out during the plant vegetation period. From a physiological point of view, determinations were made in the flowering phenophyasis of plants, concerning:

- $\mathrm{PAR}=$ photosynthesis active radiation $\left(\mu \mathrm{mol} / \mathrm{m}^{2} / \mathrm{s}\right)$, determined with $\mathrm{LC} \mathrm{PRO}+$

- $\mathrm{T}=$ temperature at the level of the analyzed leaves $\left({ }^{0} \mathrm{C}\right)$, determined with LC PRO +

- $\mathrm{F}=$ Photosynthesis rate $\left(\mu \mathrm{mol} \mathrm{CO}_{2} / \mathrm{m}^{2} / \mathrm{s}\right)$, determined with $\mathrm{LC} \mathrm{PRO}+$

- $\mathrm{E}=$ foliar sweating rate $\left(\mathrm{mmol} \mathrm{H}_{2} \mathrm{O} / \mathrm{m}^{2} / \mathrm{s}\right)$, determined with $\mathrm{LC} \mathrm{PRO} \mathrm{+}$

- The average foliar Surface of a leaf was determined using the Area Metter AM 300, in the flowering phase of the plant

- The sugar concentration in the sorghum plants was determined with a Hand Refractometer, in the milk wax of the grain phase of the plant. The Refractometer has a 0 $32 \%$ BRIX scale and temperature compensation in the range 10-30 degrees Celsius. 
In the phase of milk wax of the grain, determinations were made on the size of the plant, the diameter of the stem and the production of biomass.

\section{Results and discusions}

Analyzing the characteristics of the plant at 5 hybrids of sweet sorghum studied on the sandy soils, a plant height was revealed within the range of 227-299 cm and a diameter of the stem of 18.4-22.08 mm (Table 1). They were distinguished by above-average values, the hybrids of Shaşm 1 and Shaşm 2. The measurements of sugar in the strains, carried out in the wax-milk phase of the grain, underlined values of $14.8-16.7 \%$, with a maximum at the hybrid Es Athena. Out of the 5 hybrids, 3 registered above-average values in terms of sugar content in the strains. The results obtained in Romania [4, 5], highlighted a highsoluble solid content in some hybrids of sweet sorghum cultivated in suthwestern Romania. Thus, the total quantity of sugar ranged between $14.02 \%$ and $15.87 \%$, of which a higher percentage $67.74 \%$ to $79.43 \%$ is the non-reducing sugar. The leaf area index (Table 1) recorded values of 8.28-9.85, with an average of 9.12, highlighting the hybrids of Shaşm 2, Es Athena and Shaşm 1. Numerous researches have resulted in a positive correlation between the height of the sweet sorghum plant and the accumulation of sugar. Since the physiological mechanisms underlying the accumulation of sugar in the sweet sorghum are not well understood, it is not known whether the apparent association between the accumulation of sugar in the stem and the height of the plant is the result of selection or dictated by physiological or genetic constraints. In this regard, the research conducted at the University of Florida Suwannee Valley Agricultural Extension Center (SVAEC) near Live Oak, Florida, USA [14] highlighted the role of shading on the accumulation of sugar in the hybrids of sweet sorghum with contrasting heights, and the results achieved showed that the increased concentration of sugar in the sweet sorghum is not conditionated on the fact that the plants are high, which makes it feasible to develop short lines with high sugar content.

Table 1. Morphological and quality qualities of the sorghum hybrids cultivated under the conditions of the psamosoils

\begin{tabular}{|l|l|c|c|c|c|c|}
\hline $\begin{array}{c}\text { No } \\
\text { var. }\end{array}$ & \multicolumn{1}{|c|}{ Hybrid } & $\begin{array}{c}\text { Plants } \\
\text { height } \\
\mathrm{cm}\end{array}$ & $\begin{array}{c}\text { Diameter } \\
\text { of the } \\
\text { stem } \\
(\mathrm{mm})\end{array}$ & $\begin{array}{c}\text { \% Sugar } \\
\text { in the } \\
\text { milk } \\
\text { phase- } \\
\text { wax of } \\
\text { the grain }\end{array}$ & $\begin{array}{c}\text { Leaf } \\
\text { area } \\
\text { index } \\
\text { (LAI) }\end{array}$ & $\begin{array}{c}\text { Dry } \\
\text { substa } \\
\text { nce } \\
(\%)\end{array}$ \\
\hline 1 & SHAȘM 1 & 297 & 22.08 & 15.8 & 9.62 & 26.08 \\
\hline 2 & SHAȘM 2 & 299 & 21 & 16 & 9.85 & 24.13 \\
\hline 3 & ES ATHENA & 274 & 18.4 & 16.9 & 9.66 & 23.35 \\
\hline 4 & BMR GOLD & 227 & 19.83 & 14.8 & 8.55 & 22.59 \\
\hline 5 & SUPERSILE & 286 & 19.75 & 15 & 8.28 & 23.37 \\
\hline Average & 276.6 & 20.21 & 15.54 & 9.192 & 23.9 \\
\hline \multicolumn{2}{|l|}{ Minimum } & 227 & 18.4 & 14.8 & 8.28 & 22.59 \\
\hline \multicolumn{2}{|l|}{ Maximum } & 299 & 22.08 & 16.7 & 9.85 & 26.08 \\
\hline
\end{tabular}


Analyzing the diurnal variation of the photosynthesis rate, determined during the flowering period of the plant (Figure 1), a maximum value was found at lunchtime, which, at the hybrids Es Athena, BMR Gold and Super Sile, decreased slightly in intensity at 15 o'clock. At the Hybrids Shaşm 1 and Shaşm 2 the values of photosynthesis recorded at 15 o'clock were below the level of values at 9 o'clock, because in these hybrids the values of the stomata conductance were very small, the closure movements of the stomatas influencing the exchange of gases at the leaf level. The average daily values were between 22.07-31.69 $\mu \mathrm{mol} \mathrm{CO} 2 / \mathrm{m}^{2} / \mathrm{s}$, the best results being recorded at the Super Sile hybrid.

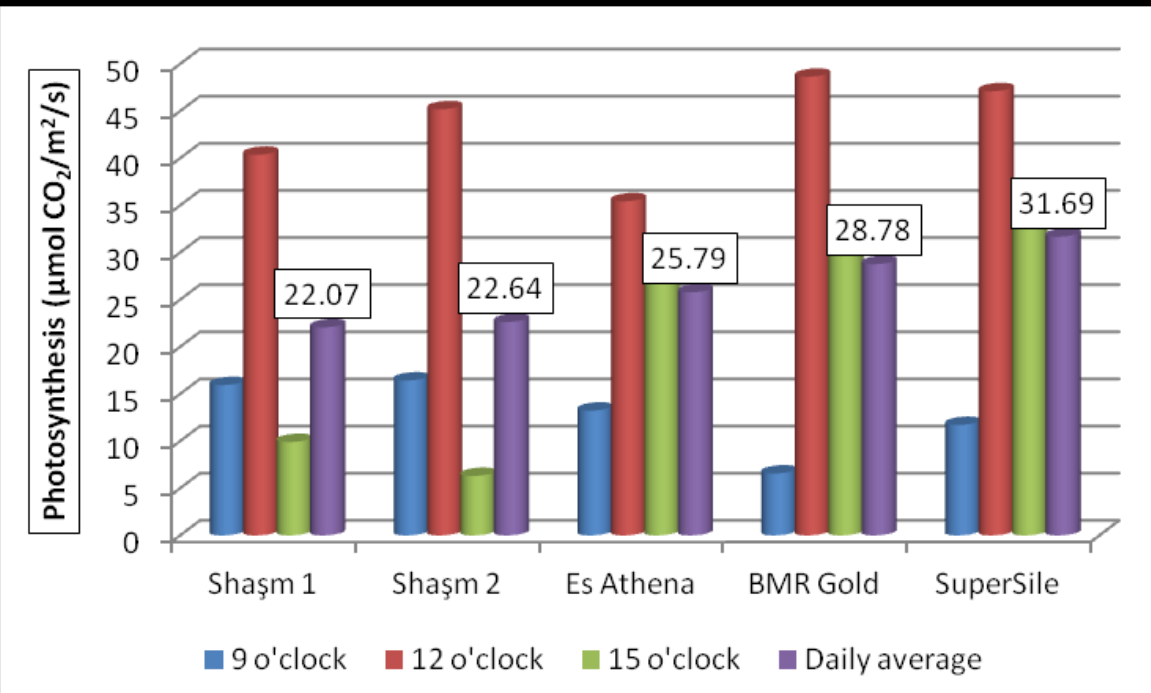

Fig. 1. The diurnal variation of photosynthesis in hybrids of sorghum cultivated in the conditions of psamosoils

The foliar sweating process presented a dynamic similar to the photosynthesis process, with the maximum diurnal being recorded at 12 o'clock, with values ranging from 2.69 $\mathrm{mmol} \mathrm{H}_{2} \mathrm{O} / \mathrm{m}^{2} / \mathrm{s}$ to the Shaşm 1 hybrid and $5.55 \mathrm{mmol} \mathrm{H} \mathrm{H}_{2} \mathrm{O} / \mathrm{m} 2 / \mathrm{s}$ to the SuperSile hybrid. The average daily values ranged from 1.91 to $3.64 \mathrm{mmol} \mathrm{H}_{2} \mathrm{O} / \mathrm{m}^{2} / \mathrm{s}$ (Figure 2).

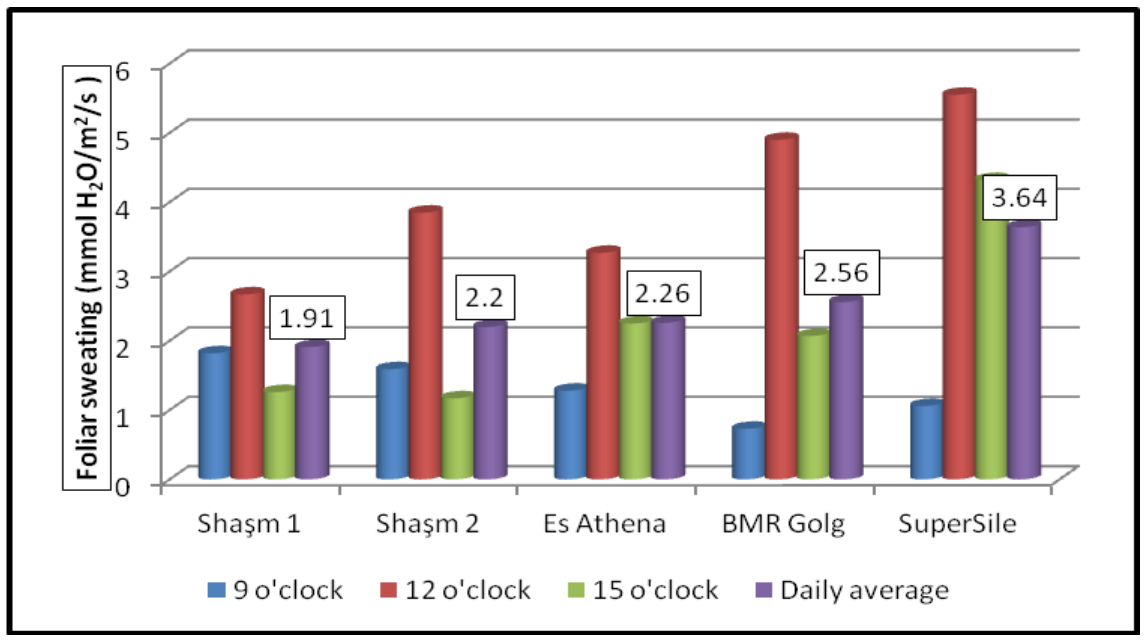

Fig. 2. The diurnal variation of foliar sweating of sweet sorghum hybrids 
In this phenophyase of vegetation, the intensity of the two physiological processes (the plant photosynthesis and the foliar sweating) were positively correlated, the plants with intense photosynthetic activity also presenting higher levels of sweating. The hybrid of sweet sorghum Shaşm 1 presented the best adaptability to the conditions of the psamosoils in southern Oltenia, recording the lowest rate of sweating, with a daily average of 1.91 mmol $\mathrm{H}_{2} \mathrm{O} / \mathrm{m}^{2} / \mathrm{s}$ correlated with a large percentage of dry substance accumulated in the leaves $(26.08 \%)$. Sorghum is one of the cultivated plants that requires the smallest quantity of water. One of its peculiarities is the fact that it has a $\mathrm{CO}_{2}$ absorption mechanism "in $\mathrm{C}_{4}$ ", which gives it better photosynthesis performance, therefore better efficiency in drought or high temperatures. In addition, thanks to its very dense root system (which can descend to more than 2 meters in deep and well-prepared soil), sorghum can absorb and use more efficiently the water and nutrients in the soil. Its total water requirements (soil reserves + rain + irrigation) is around $400-500 \mathrm{~mm}$ [7]. Water maintains the cells in the state of turgescence and ensures the acid-base balance of the plants. In the photosynthesis process, chlorophyll cells activate normally when their protoplastics are at a hydration degree of 80$85 \%$. In other species, for example barley, this process stops at $80 \%$ and in beans at $82 \%$, while in sorghum and millet, it also works at $35 \%$. The efficiency of transpiration (ET), an indispensable phenomenon associated with drought tolerance of plants is the amount of biomass produced ( $\mathrm{kg}$ dry matter) per unit of transpired water $\left(\mathrm{m}^{3}\right)[6,15]$. Improving the efficiency of transpiration, especially in dry environments, can have a major impact on improving productive yield, because high transpiration efficiency will allow plants to either postpone the symptoms of the stress or produce more biomass from the same amount of soil moisture available or a combination of both [16]. Improving genetic training as well as crop management practices can lead to greater transpiration efficiency. The values of the efficiency of transpiration at the physiological maturity of the sorghum were between 3.21 and $7.55 \mathrm{~kg} / \mathrm{m}^{3}[11,15]$. However, little is known about the efficiency of foliar sweating in sorghum and how, or if, it changes with the stage of growth. The production results on biomass obtained at harvest, in the milk wax phase, highlighted a level of yields in the range $61400-90150 \mathrm{~kg} / \mathrm{ha}$, with a maximum of the Shaşm 2 hybrid, which made a production difference of $12976 \mathrm{~kg} / \mathrm{ha}$, compared to the average of hybrids. BMR Gold and SuperSile hybrids produced below the witness level with significantly negative differences (Table 2).

Table 2. Production of biomass obtained hybrids of sweet sorghum cultivated under the conditions of the psamosols

\begin{tabular}{|c|c|c|c|c|c|c|}
\hline \multirow{2}{*}{$\begin{array}{l}\text { No } \\
\text { var. }\end{array}$} & \multirow[t]{2}{*}{ Hybrid } & \multicolumn{2}{|c|}{ Production } & \multirow{2}{*}{$\begin{array}{l}\text { Diference } \\
\text { of energy } \\
\text { (Mcal/ha) }\end{array}$} & \multirow{2}{*}{$\begin{array}{c}\text { Net } \\
\text { energy } \\
\text { growth } \\
\text { (Mcal/ha) }\end{array}$} & \multirow{2}{*}{$\begin{array}{c}\text { Energy } \\
\text { consumption } \\
\text { per kg }(\%)\end{array}$} \\
\hline & & $\begin{array}{l}\text { Biomass } \\
\mathrm{kg} / \mathrm{ha}\end{array}$ & $\begin{array}{l}\text { Energy } \\
\text { Mcal/ha }\end{array}$ & & & \\
\hline 1 & SHAȘM 1 & 87200 & 86415.2 & 9947.66 & 9748.707 & 88.69 \\
\hline 2 & SHAȘM 2 & $90150 *$ & 89338.65 & 12871.11 & 12613.69 & 85.84 \\
\hline 3 & ES ATHENA & 81870 & 81133.17 & 4665.63 & 4572.317 & 94.36 \\
\hline 4 & BMR GOLD & $65250^{\circ}$ & 64662.75 & -11804.8 & -11568.7 & 117.83 \\
\hline 5 & SUPERSILE & $61400^{0}$ & 60787.94 & -15620.1 & -15307.7 & 125.03 \\
\hline \multicolumn{2}{|c|}{ Average (Mt.) } & 77174 & 76467.54 & $\mathrm{Mt}$ & $\mathrm{Mt}$ & 100 \\
\hline \multicolumn{7}{|c|}{ LSD $5 \%=11070 \mathrm{~kg} / \mathrm{ha}$} \\
\hline \multicolumn{7}{|c|}{ LSD $1 \%=16100 \mathrm{~kg} / \mathrm{ha}$} \\
\hline \multicolumn{3}{|c|}{ LSD $0.1 \%=24150 \mathrm{~kg} / \mathrm{ha}$} & & & & \\
\hline
\end{tabular}


The energy equivalent used to calculate the energy obtained at the sweet sorghum is $0.991 \mathrm{Mcal} / \mathrm{kg}$ biomass [9]. The calculation of the energy consumption was also taken into account in the amount of $0.02 \%$ in the collection of the crops increase. Compared to the average of hybrids in which the energy value of 76467.54 recorded Mcal / ha, three sweet sorghum hybrids was recorded increases in energy. The lowest energy consumption per $\mathrm{kg}$ of product was recorded in the Shaşm 2 hybrid (85.84\%)

The intra-group competition between plants is carried out during the development of the foliar system and the root system, and the results show that higher increases in energy biomass are achieved as the plant is cultivated in a complex similar to that of it's origin, [12]. Bioenergy is, in principle, energy obtained from biomass, because, while growing, plants capture solar energy and carbon dioxide with which they build the organic matter in which energy is stored. Studies show that the use of bioenergy in the EU could double or triple without damaging the environment and without reducing the production of food, feedingstuffs or raw materials. In the notion of bioenergy are identified the following types: biomass, bioethanol, biodiesel, biogas. There are many potential sources of bioenergy that are currently under-exploited, such as biomass of certain plants, which incorporated into the soil can contribute to reducing the inputs in agriculture. The increase in the bioenergy efficiency of plants, by choosing the appropriate assortment of a particular area, could make a substantial contribution to reducing energy security problems generated by global climate changes [2].

The production results recorded at the sweet sorghum were positively correlated, distinct significantly with the leaf area index determined in the flowering phase of the plant (Figure 3).

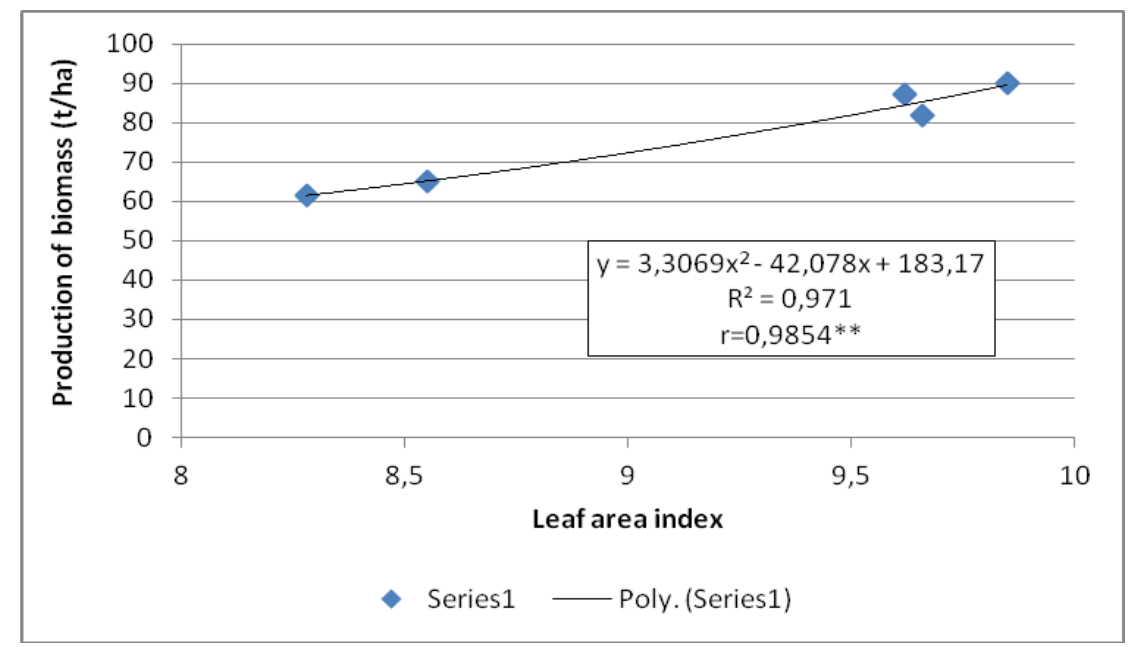

Fig. 3. Correlation between the foliar surface index and the production of biomass obtained by the hybrids of sweet sorghum cultivated under the conditions of the psamosoils

\section{Conclusions}

1. The measurements of sugar in the strains carried out in the milk wax phase of the grain revealed values of $14.8-16.7 \%$, with a maximum at the hybrid Es Athena.

2. The daily average values of photosynthesis recorded in the 5 sweet sorghum hybrids were contained between 22.07-31.69 $\mu \mathrm{mol} \mathrm{CO} 2 / \mathrm{m}^{2} / \mathrm{s}$, with the best results at the Super Sile hybrid. 
3. The Shaşm 1 hybrid presented the best adaptability to the conditions of the psamosoils in southern Oltenia, recording the lowest rate of transpiration, with a daily average of 1.91 mmol $\mathrm{H}_{2} \mathrm{O} / \mathrm{m}^{2} / \mathrm{s}$ and a large percentage of the dry substance accumulated in the leaves $(26.08 \%)$.

4. The production results of biomass obtained at harvest, in the milk wax phase, highlight a level of eficiency in the range $61400-90150 \mathrm{~kg} / \mathrm{ha}$, with a maximum of the Shaşm 2 hybrid, which made a difference in production compared to the average of hybrids and energy consumption per $\mathrm{kg}$ within the limits $85.84-125.03 \%$

5 . The production results recorded at the sweet sorghum were positively correlated, distinct significantly with the leaf area index determined in the flowering phase of the plant $(\mathrm{r}=$ $0.9854 * *)$.

\section{Acknowledgement}

This work was supported by a grant of the Romanian Ministery of Research and Innovation CCDI - UEFISCDI, "COMPLEX SYSTEM OF INTEGRAL CAPITALIZATION OF AGRICULTURAL SPECIES WITH ENERGY AND FOOD POTENTIAL", project number PN-III-P1-1.2-PCCDI-2017-0566, Contract no. 9PCCDI / 2018, within PNCDI III.

\section{References}

1. A. Almodares, M. R. Hadi, H. Ahmadpour, Sorghum stem yield and soluble carbohydrates under different salinity levels. African Journal of Biotechnology, vol. 7, pp. 4051- 4055 (2008).

2. A. Karp, I. Shield, Bioenergy from plants and the sustainable yield challenge, DOI: 10.1111/j.1469-8137.2008.02432.x., Journal New Phytologist, vol. 179, Issue 1,_pp.15-32, (2008).

3. B.V.S. Reddy, S. Ramesh, S. P. Reddy, B. Ramaiah, P.M. Salimath, R. Kachapur, Sweet sorghum - a potential alternative raw material for bioethanol and bioenergy. Int Sorghum Millets Newsl, vol. 46, pp. 79-86, (2005).

4. C. Babeanu, Gh. Matei, A. M. Dodocioiu, Evaluation of sugar content in stem juice from sweet sorghum hybrids grown in south west of Romania. Annals of the University of Craiova - Agriculture, Montanology, Cadastre Series,vol. 47, pp 2529, (2017).

5. Gh. Matei, Study on yield features of sweet sorghum hybrids grown in south west of Romania. 16th International Multidisciplinary Scientific GeoConference SGEM 2016, www.sgem.org, SGEM2016 Conference Proceedings, ISBN 978-619-710568-1 / ISSN 1314-2704, Book 6, vol. 1, DOI: 10.5593/SGEM2016/B61/S25.104, pp: 783-790, (2016).

6. H. Kun-Jun, W. D. Pitman, K. Misook, F. D. Donal, W. A. Montgomery, E. Michael, Mc Cormick, G. Aita, 2012, Ethanol production potential of sweet sorghum assessedusing forage fiber analysis procedures, GCB Bioenergy, vol. 5, doi: 10.1111/j.1757-1707.2012.01203.x, pp. 358-366, (2013).

7. https://www.sorghum-id.com/ro/conservarea-resurselorin-apa-sorgulo-solutiesigura, Sorghum ID - The Future is on the sorghum-the First European Congress of Sores - a founding act: "Sorghum in Europe: A real potential", Bucharest (2016).

8. I. Antohe, Achievements in the improvement of sorghum, Annals. N.A.R.D.I. Fundulea, Vol. 75, 2007, JUBILEE VOLUME, pp. 137-157, (2007).

9. I. Tesu, V. Baghinschi, Energy and agriculture, Ed. Ceres, Bucharest, (1984).

10. K. S. Vinutha, L. Rayaprolu, K. Yadagiri, A. V. Umakanth, J. V. Patil, P. Srinivasa Rao, Sweet Sorghum Research and Development in India: Status and 
Prospects. Sugar Tech, DOI 10.1007/s12355-014-0302-9, ISSN: 0972-1525, Vol. 16 (2), pp:133-143 (2014).

11. M. Balota, W.A. Payne, W. Rooney, D. Rosenow, Gas exchange and transpiration ratio in sorghum. Crop Science, vol. 48, pp. 2361-2371, (2008).

12. S. N. Olson, K. Ritter, W. Rooney, A. Kemanian, B. A. McCarl, Y. Zhang, S. Hall, D. Packer, J. Mullet, High biomass yield energy sorghum: developing a genetic model for C4 grass bioenergy crops. Biofuels, Bioproducts and Biorefining, vol. 6, issue 6, pp. 640-655, (2012).

13. S. R. Khalil1, H. A. Hussien, S. R. Abazied, New Approach for Using Different Forms of Sweet Sorghum Syrup in Cake Making. World Journal of Food Science and Technology, vol. 2, No. 2, doi: 10.11648/j.wjfst.20180202.11, www.sciencepublishinggroup.com, pp. 25-32, (2018).

14. S. Shukla, T. J. Felderhoff, A. Saballos, W. Vermerris, The relationship between plant height and sugar accumulation in the stems of sweet sorghum (Sorghum bicolor (L.) Moench), Field Crops Research, vol. 203, 1, pp. 181-191, (2017).

15. Z. U. Xin, R. Aiken, J. Burke, Genetic diversity of transpiration efficiency in sorghum. Field Crops Research, vol. 111, pp. 74-80, (2009).

16. Z. Xin, C. Franks, P. Payton, J.J. Burke, A simple method to determine transpiration efficiency in sorghum. Field Crops Research, vol. 107, pp. 180-183, (2008). 